\title{
Kerkorde en doop - Toegespits op twee gereformeerde kerkordes
}

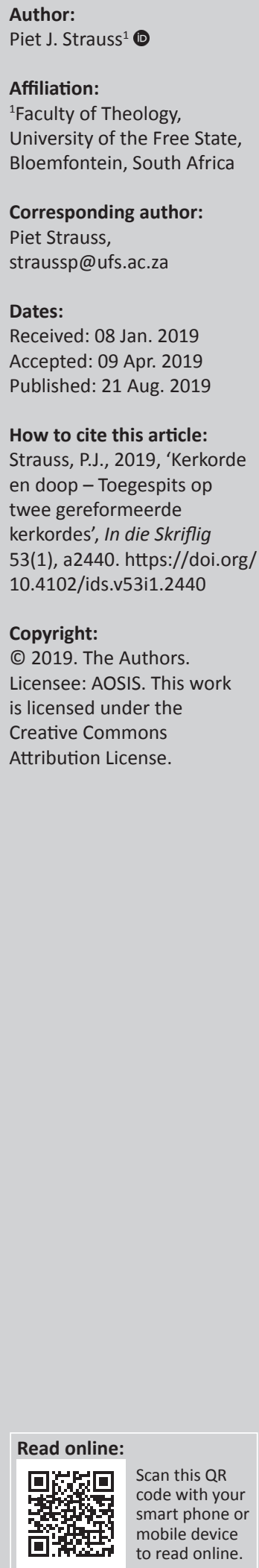

Church order and baptism - with reference to two reformed church orders: The purpose of a church order is not an end itself, but to serve the church in its calling as an institute of the Christian faith. A church order and church polity as a subject should serve the church. Thus, the theme on church order and baptism implies the serving identity of the first in connection with the latter. It implies a church order which serves and secure the sacrament of baptism in keeping to its biblical character or identity when served. This is an order which assists the sacrament of baptism as a sacrament to explain, convey and guarantee its message. From a reformed perspective the triune God is the central acting figure in baptism. Baptism is about connecting them to and establishing people in the covenant of grace of the triune God - and about securing it.

Keywords: Baptism guarantees covenant of God's grace; The sacrament of baptism visible proclamation of the Word of God; Reformed people baptise as soon as possible; Church orders give correct procedure for an accepted baptism; Church orders secure Scriptural baptism.

\section{Agtergrond en probleemstelling}

Jesus Christus is die Hoof van sy kerk: sy kerk met al die kante of fasette wat daaraan verbonde is.

Verskeie kerke met stelsels van kerkregering wat soms skerp van mekaar verskil, bely hierdie waarheid as ' $n$ kern- of belydeniswaarheid. Dit is ' $n$ waarheid waaroor die 'heilige, algemene, Christelike kerk' soos deur Christengelowiges bely (vgl. Apostolicum 1982:118), nie onderhandel nie. 'n Waarheid waarsonder die gelowiges as die geestelike liggaam van Christus (1 Kor 1:1-2; 12:12-31) of as 'n gebou, tempel en saailand van God (1 Kor 3:9, 16) soos vergestalt in die kerk as samelewingsverband, die sin van sy bestaan verloor (Jonker 1965:6).

Omdat Christus sy kerk deur sy Woord en Gees versamel (Heidelbergse Kategismus - HK - vraag en antwoord 54; NG Kerk-Uitgewers 1982:53) en die kerk as sy liggaam uit Hom as die Hoof deur sy Woord en Gees gebou, groei en geregeer word (Ef 4:12-16), is Christusgesag Woordgesag (Strauss 2010:29). Christusregering in die kerk is ten diepste regering deur sy Woord en Gees. 'n regering waarvoor die Heilige Gees die gelowiges toerus of vervul (Eks 31:3; Ef 5:18 binne die raamwerk van Ef 4:17-6:20; Strauss sa:16-20). Naas die direkte leiding van die Woord en Gees van God in mense vir die regering van die kerk, regeer die Gees die kerk deur die Woord in geroepe ampdraers (Kleynhans 1984:3-5).

Dit beteken dat die inhoud (mense, strukture en gebeure) van die kerk as 'n geloofsverband of 'n liggaam van Christengelowiges deur die Woord en Gees van God bepaal moet word. Die lewende Woord van God moet die eerste en die laaste sê in die kerk hê.

Die HK stel die vraag: Terwyl ons slegs deur die geloof deel aan Christus en al sy weldade kry, waar kom so 'n geloof vandaan? (HK vr 65; NG Kerk-Uitgewers 1982:56). Die verkorte antwoord is: Die Heilige Gees bewerk die geloof in 'ons' (die kerk of die gelowiges) se harte deur die Woord en versterk dit deur die sakramente (Trimp 1983:7).

Die Heilige Gees bekwaam die kerk en sy regering deur die genademiddele van Woord en sakramente. Die gelowiges of 'gemeente wat tot die ewige lewe uitverkies is' (HK vr 54, NG KerkUitgewers 1982:53) word geroep en opgebou deur die Gees, die Woord en die sakramente. Daarom bely die Nederlandse Geloofsbelydenis (NGB) artikel 29 dat die ware kerk daar is waar Woord en sakramente suiwer bedien en die kerklike tug - al drie spruit uit Woordgehoorsaamheid gehandhaaf word (Bavinck 1967:365; NG Kerk-Uitgewers 1982:29). Die Heilige Gees verbind ons deur die Woord van God as sy lewensboodskap én ons gelowige aanvaarding daarvan, aan die 
Here (Strauss 2010:81, 82). Hy verseël hierdie boodskap aan ons harte deur die sakramente as sigbare genademiddele van God (HK vr 66, NG Kerk-Uitgewers 1982:66; Sizoo sa:314). Die ware kerk is daar waar Woord, sakrament en tug soos deur God gegee, die gelowiges deur die Christelike geloof bind en versamel. Die ware kerk bou op Woord en sakrament wat die kerklike tug vir die verlostes as verloste sondaars impliseer. Met sy klem op God se vryspraak uit genade om Christus ontwil én die besef dat ons in die hiernoumaals nie volmaak is nie, het Martin Luther aan die gelowiges die status van simul justus ac peccator gegee: die gelowiges is tegelyk geregverdig én sondaars, of dan geregverdigde sondaars (De Jong 1987:170).

In hierdie proses het gereformeerde kerke tot die oortuiging gekom dat I Korintiërs 14:40 se opdrag dat alles 'gepas en ordelik' moet geskied, 'n opdrag wat in Korintiërs vir die samekoms van die gemeente gebruik word, op alle kerklike bedrywighede van toepassing is. Nauta verstaan Calvyn so dat hy van 1 Korintiërs 14:40 'een regel' maak waaraan alle 'uitwendige' werk van die kerk gemeet moet word (Nauta 1971:10, 11). Volgens Calvyn het die Here aan die kerk die vryheid gegee om op sy eie manier sy regering en seremonies binne die raamwerk van die Skrif te hanteer (Sizoo sa:229). Vir gereformeerdes, op die spoor van Calvyn, is 1 Korintiërs 14:40 'n locus classicus of Skriftuurlike begronding vir 'n kerkorde (Kruger et al. 1966:11; Nauta 1971:11; NGKO 1964:2; Van der Linde 1983:7; vgl. Coertzen 1991 vir die titel van sy publikasie). ${ }^{1}$

As die kerkregering van Christus deur sy Woord en Gees (hierdie begrip is eg Calvyns, Sizoo sa:8) is, en die sakramente in hulle Skrifmatige bediening die geloof in God verseël en versterk, $^{2}$ en as die ware kerk daar is waar die gelowiges Woordgetrou rondom die Woord, sakrament en tug vergader, mag die regering van die kerk aan die hand van 'n kerkorde nie meer as ' $n$ dienende regering en orde wees nie. Dit is 'n hulpmiddel wat die Christusregering deur die Woord van God én die sakramente as sy sigbare Woorde verseker. Daarom noem Plomp kerkreg 'n dienende reg en kerkordes dienende ordes (Plomp 1992:38-40). ${ }^{3}$

'n Kerkorde moet die kanale wees vir die onbelemmerde deurvloei van die Woord in alle aspekte van die kerklike lewe. 'n Kerkorde moet 'n orde wees wat die gesag en regering van die Woord in die kerklike lewe verseker (Strauss 2010:15).

\footnotetext{
1.1 Korintiers 14:40 is die enigste Bybelteks wat in die Kerkorde van die Nederduitse Gereformeerde Kerk (NGKO) en sy voorbeeld, naamlik die Kerkorde van 1959 van Gereformeerde Kerk (NGKO) en sy voorbeeld, naamlik die Kerkorde van 1959 van
die Gereformeerde Kerke in Nederland (GKN), die GKN-KO, voorkom (NGK 1962:2; die Gereformeer
Nauta 1971:43)

2.Calvyn noem die sakramente nuttige hulpmiddels wat die geloof voed en versterk (Sizoo sa:5). Hy brei hierop uit deur na die sakramente te verwys as uitwendige tekens en seëls waardeur die Here sy belofte van goeie guns aan ons 'consciëntiën' [gewetes] verseël om die swakheid van ons geloof te versterk en ons in staat te ste om ons 'vroomheid' [gehoorsaamheid] voor God en die mens te betuig (Sizoo sa.:314). Calvyn se invloed blyk uit die HK, vr. 60 se omskrywing van sakramente as 'sigbare, heilige tekens en seëls wat God ingestel het om ons die belofte van die Evangelie nog beter te laat verstaan en dit te beseël' (NG Kerk-Uitgewers 1982:56).

3.Om die dienende karakter van ' $n$ kerkorde te beklemtoon, noem Smit en Van der Walt ' $n$ Skrifverantwoorde kerkorde ' $n$ 'bepaalde wyse van Woordverkondiging'. Die kerkorde staan prinsipieel in diens van die Woord, of is gebonde aan Skrifbeginsels vir die kerk, of aan die bepalende karakter van die Woord (Smit \& Van der Walt 1989:60).
}

Dit moet 'n Orde wees wat die kerk help om sy geloofstaak en kerklike roeping so goed 'mogelijk' te vervul (Nauta 1971:13). Dit is 'n Orde wat die verseëlende, geloofsversterkende krag van die sakramente as Woordgetroue genademiddele dien en kanale verskaf vir die Skrifgetroue bediening van die doop en die nagmaal. 'n Kerkorde moet duursame bepalings gee ${ }^{4}$ wat die impak van die Woord fasiliteer en nie verduister nie - dit sou kollegialisties of mensgemaak wees of so niksseggend en skraal, dat dit geen invloed op die kerklike lewe het nie. 'n Kerkorde in diens van die Skriftuurlike bediening van die sakramente, dien die geestelike welsyn van die kerk (Bouwman 1985:325-326; Nauta 1971:12).

Daarom moet die kerkorde die doop en Skrifgebonde lewe van die gedooptes in gemeenskap met Christus en met mekaar, 'kerklijk' beveilig (Nauta 1971:9). Smit en Van der Walt glo dat 'n kerkorde die Skriftuurlike doop teen vervalsing moet beskerm. Die kerkorde moet die kerklike ruimte beveilig waarbinne die doop, 'soos God dit in sy Woord verordineer het, bedien kan word'. Vir hierdie outeurs word die 'verbonds-' sowel as die 'bekeringsdoop' dogmaties begrond, maar die bediening daarvan breedweg of ten opsigte van sy algemene rigting, kerkordelik gereël. Die kerkorde gee nie 'n antwoord op elke denkbare vraag, bybels, dogmaties en prosedureel, oor die doop nie (Smit \& Van der Walt 1989:60-61).

Hierdie artikel konsentreer op die vraag na 'n gereformeerde kerkorde - prinsipieel beskou - en die bediening van die doop: die ordelike bediening van die verbondsdoop of doop as 'n kerklik-dogmatiese gegewe in die gereformeerde kerke (Trimp 1985:68). As gevallestudies word die kerkordes van die Gereformeerde Kerke in Suid-Afrika (GKSA-KO) en die Nederduitse Gereformeerde Kerk (NGKO) op hierdie punt ondersoek. Die vertrekpunt is dat die kerkorde nie die aard en inhoud van die Skriftuurlike doop bepaal nie, maar uit die hoek van kerklike prosedure probeer verseker dat sy Skriftuurlike aard en inhoud die orde en bediening van die doop bepaal (Smit \& Van der Walt 1989:59).

\section{Die verbondsdoop - 'n sakrament}

Daar is reeds aangevoer dat kerklike sakramente tekens en seëls van die Here is om aan die gelowiges die beloftes van die evangelie te verseker of te verseël. Tekens en seëls waarmee God sy genade of sy verbondsbelofte, sy belofte dat Hy Homself aan hulle as hul God verbind, aan die gelowiges waarborg (Kock 1975:39-41, 143-144). Dit geld vir die doop én die nagmaal as die twee erkende sakramente in gereformeerde kerke. Daarmee kies hierdie kerke vir Calvyn se siening van die sakramente teen twee uiterstes: die Roomse realisme wat van die wyn (of water) en die brood die ware bloed en liggaam van Christus na die instellingswoorde van die priester wil maak, en die

4.Dieselfde skrywers bepleit 'n bondige maar duidelike kerkorde wat die bedieningsfasette van die doop of die prosedure by die bediening van die doop aan die Skrifnorm laat beantwoord. Om as 'n tipiese kerkorde hieraan uitvoering te gee, moet hierdie orde die opdragte vir die doopbediening sistematiseer en saamvat (Smit \& Van der Walt 1989:60). 
Zwingliaanse simbolisme wat na die tekens as blote tekens of simbole van die bloed en liggaam van die Here Jesus verwys (Heick 1965:215-230).

Onder die invloed van Calvyn (Sizoo sa:347) beskou gereformeerdes die doop as 'n sakrament wat die inlywing (Calvyn in Sizoo sa:347, 360; Smit \& Van der Walt 1989:59 praat van 'inwyding', maar laasgenoemde wissel dit af met 'inlywing'; Smit \& Van der Walt 1989:65) van die gelowiges en hulle kinders deur God in sy verbond van genade verseël, terwyl die Here deur die nagmaal die inblywing van die gelowiges in dieselfde verbond waarborg. Daarom dat die doop eenmalig is en herdoop God se verbondsbelofte soos deur die doop verseël in beginsel betwyfel en bevraagteken. 'n Rede waarom die Reformatore skerp teen die praktyke van die Wederdopers gekant was (De Jong 1987:179-187; Trimp 1985:68-72). In beide gevalle gaan dit om 'n teken en seël van God wat Hy aan die gelowiges as 'n waarborg van sy beloftes gee en nie ' $n$ getuienis of ' $n$ belydenis van die gelowiges nie. Die sakramente sê iets van God vir die mens en nie van die mens aan God of omgewing nie. Daarom dat die HK daarvan praat as heilige tekens en seëls. Heilige tekens en seëls wat deur die Here God as die Gewer daarvan geheilig is. Smit en Van der Walt skaar hulle hierby as hulle aanvoer dat 'dit in die doop uitsluitlik gaan om wat God vir die mens doen en nie om wat die mens self doen nie' (Smit \& Van der Walt 1989:66). Trimp verbind die verbondsdoop aan respek vir die 'beslag' lê van die Here God op die sondaarmens téénoor respek vir 'menselijke religieuse mondigheid en besluitvaardigheid' in die sogenaamde bekeringsdoop: 'Niet het menselijk subject, maar God handelt in het sacrament' (Trimp 1985:70-71).

Vir Smit en Van der Walt is die doop 'een van die konstitutiewe faktore van die kerk' (Smit \& Van der Walt 1989:59), 'n 'fundamentele samebindende faktor van die kerke'. Kerkeenheid as geloofseenheid bevat eenheid in 'een en dieselfde doop' (hulle gebruik Ef 4:5-6). Daarom is die prosedure aan gesamentlike kerklik vasgestelde doopformuliere as 'n uitdrukking van kerkeenheid gebind. Dwaalleer deur verkeerde aksente van die individuele bedienaar kan by die bediening van die doop ontstaan en tot ' $n$ versplintering en selfs ' $n$ ontbinding van die kerk lei (Smit \& Van der Walt 1989:69). Teen hierdie agtergrond is dit duidelik waarom die Drie Formuliere van Eenheid (in die geloof) soos bely deur kerke in die NederlandsGereformeerde tradisie, hulle uitdruklik uitlaat ten gunste van die verbondsdoop: aan die kinders van verbondsouers en nie-gedoopte volwassenes by wie daar 'n nuwe verbondslyn vorm na hulle bekering (NG Kerk-Uitgewers 1982:32-34, 57-58). Boonop is 'n saak van 'n konstitutiewe of fundamenteelbindende aard in die kerk ' $n$ kernsaak in die geloof wat juis daarom op die vlak van 'n belydenis lê. ${ }^{5}$ 'n Saak wat nie ligtelik hanteer moet word nie en kerkordelik, ook in die woorde van Nauta, 'beveilig' moet word.

\section{Vier elemente van 'n sakrament}

Gereformeerdes is van oordeel dat 'n sakrament as 'n sigbare teken en seël uit vier konstituerende elemente bestaan wat in die bediening daarvan elkeen sy regmatige plek inneem en wat geïntegreerd die verbondsbeloftes van God aan die kerk deur die sakramente verseël (Strauss 2010:98). Dit is verder elemente wat hier nie in volgorde van belangrikheid gestel word nie, en omdat elke element belangrik is, kerkordelik 'beveilig' moet word.

Die eerste is die sigbare tekens van brood en wyn (nagmaal) of water (doop). Hierdie tekens moet so na as moontlik aan die oorspronklike by die vasstelling van die sakrament wees. So iets verseker dat Christus in sy instelling van die sakramente ten opsigte van die inhoud en betekenis daarvan ernstig geneem en die tekens in hulle Skriftuurlike eenvoud en duidelikheid oorgedra word (Trimp 1983:157). Dit gaan oor gewone wyn (rooi soetwyn), wit brood (bakkersbrood) en skoon water - uit watter bron ookal. ${ }^{6}$ Tweedens gaan dit oor die Woord wat die tekens deur die formulier in 'n nuwe konteks plaas. Dit gee daaraan die betekenis van 'dit is my liggaam ...' en 'my bloed'. 'n Betekenis wat op die liggaam en bloed van Christus dui wat gebreek en gestort is vir die sondeskuld van mense én aan hulle gegee word deur die boodskap van die Skrif wat die doel van die tekens verduidelik. Derdens word die sakramente verseël aan hulle wat die tekens en die formulier, saam die betekende saak, in die geloof aanvaar. Aan hulle wat deur hulle geloof in die Woord verbind word aan die innerlike reinigingseffek van die water as die bloed van Christus. Hulle wat die boodskap van gebreekte brood en gestorte wyn in die geloof eet en drink (Dingemans 1987:176-177). Deur hulle doop en hulle ouers wat hierdie doop mettertyd as ' $n$ feit van die lewe aan hulle oordra, word die inlywing van die kinders van gelowiges in die verbond verseël en bevestig. 'n Verseëling wat aan hulle 'n godgegewe, stabiele bedding gee waarbinne hulle as sy kinders gehoorsaam op sy verbondseise moet antwoord. In die bedding van die genadeverbond en deur wedergeboorte en geloof soos bewerk deur sy Woord en Gees, kry hulle deel aan God se verbond van versoening. Kock praat van die uitverkorenes wat gekies is om te glo en tot gehoorsaamheid te kom as die ware gehoorsames met wie die Here sy verbond van versoening sluit (Kock 1975:41; vgl. 1 Petrus 1:1-2). H. Jonker oordeel dat die sakrament die mens in 'zijn volle mens-zijn' oproep tot versoening met God. Die sakrament ontmoedig deur sy appél op die hartsgeloof van die verbondskind 'n intellektualistiese verskraling van sy verhouding met God. Daarmee gee dit daaraan 'ongekende diepte' (Jonker sa:132, 134). Die Heilige Gees verseël die betekende saak deur die tregter van sy of haar geloof aan die gelowige Heyns (1973:1) noem die Gees die Brug tussen God en mens omdat die Heilige Gees die vierde, maar die groot aktiewe 'element' of goddelike waarborg of beseëler (Ef 1:14) van die sakrament is.

6.Water uit die Jordaanrivier in oud-Israel, of soos in Bethlehem in die Vrystaat, werk nie geestelik beter as ander skoon water nie! 
Trimp (1983:192) wys op agt 'fundamentele voorwaarden' vir ' $\mathrm{n}$ verantwoorde, betekenisvolle bediening van die doop. Voorwaardes wat aan die samestellende komponente van die sakrament verbind word en wat verseker dat hulle al vier hulle regmatige plek inneem. Voorwaardes wat 'n antwoord op die vraag na die doel van die liturgiese handeling, 'n kerkordelike prosedure by die bediening van die doop gee. Voorwaardes soos deur die skrywer hiervan gewysig, wat vir die verdere verloop van hierdie artikel sin maak. Met Trimp op die agtergrond, die volgende.

Uit die bediening daarvan moet die grond vir die doop duidelik blyk: Christus sterf vir ons sondeskuld en -smet, bemiddel deur sy versoenende sterwe ons vryspraak en regverdiging deur die geloof en deur sy opstanding die nuwe lewe en die toerusting daarvoor deur die Gees (Strydom 2014:37). Die plek van die verbond in die doop en die verantwoordelikheid van die dopeling om op die heilsbeloftes en verbondseise van God met geloof en gehoorsaamheid te antwoord, moet aangetoon word. Die verband tussen die doop as 'n belydeniswaarheid en die geloofseenheid van die kerk, moet gelê word. Die Naam van God-Drieënig en dus Christus wat deur die doop handel, moet deur die bedienaar van die Woord sowel as die doop benadruk word. God handel inisiërend in die doop en daarom is enige selfdoop ' $n$ onmoontlikheid. God se inlywing in die genadeverbond, die saak wat deur die doop verseël word, impliseer 'n hartsbreek met die mag van die sonde, versoening met God en 'n inlywing in die koninkryk van die Here. 'n Saak waarvan die doopouers en die getuies deeglik kennis moet neem. Die doop van nie-gedoopte, maar nou gelowige ouer mense loop saam met die belydenis van hulle geloof. Die gemeente is aktief by die doop betrokke: die verbondsboodskap word ter versterking van hulle geloof aan hulle bevestig en hulle neem mede-verantwoordelikheid vir die praktiese antwoorde op die doopvrae deur diegene wat daarby betrokke is.

In die gevallestudies van twee kerkordes, die GKSA-KO en NGKO, word na hierdie aspekte teruggekom.

Rondom die bediening van die doop ontstaan daar soms vrae. Vrae wat kerkordelik na die prosedure van die doopbediening herlei kan word. Vrae soos die volgende: Waarmee word gedoop?, Wat word deur die doop verseël?, Wie word gedoop en wat wil die doop oordra? Sommige van hierdie vrae is reeds beantwoord. Daarom word nie in detail hierna teruggekom nie.

\section{Vrae oor die bediening van die doop Wie doop?}

Omdat die doop 'n genadedaad van God aan die mens is, is dit 'n teken van sy vereniging met Christus; sy afsterwe van die oue mens en opstanding tot 'n nuwe lewe: sy vergifnis, vryspraak, regverdiging, redding en reiniging voor God; sy toerusting deur die Heilige Gees; en sy godgegewe wedergeboorte en nuwe lewe - Johannes 3:5 se geboorte uit water en Gees. As 'n genadedaad van God verrig die Heilige
Gees die verseëlende of sakramentele werk van die vier geïntegreerde elemente van die doop soos genoem (Smit \& Van der Walt 1989:66).

Vir die doeleindes van hierdie teken word die aard van die doop met die heilsboodskap van die Woord geïntegreer.

Gevolglik is die bediening van die doop deur Christus aan die apostels as oor- en ooggetuies van sy persoon en werk en as die fondamentlêers van sy kerk (Ef 2:20; Op 21:14) toevertrou (Hand 2:8, 21-22; 1 Joh 1:1-3; Matt 28:19). Daarmee is die bediening van die doop geïntegreer met die bediening van die Woord as 'n kerklike opdrag. Met die toeken van die prediking aan die leeramp, het die bevoegdheid om die sakramente te bedien, 'vanself' saamgegaan. Slegs hulle wat kerklik beroep en bevestig is om die Woord in die gemeentes te bedien, kon die sakramente bedien. In 1568 besluit die Konvent van Wezel in die Nederlands-Gereformeerde lyn dat die 'ambt' van die bedienaar van die Woord afgestem moet wees op (1) die 'recht snijden en toe passen' van die Woord 'zoowel in het openbaar als aan de huizen tot leering, vermaning en vertroosting', (2) die bediening van die sakramente en (3) die onderhouding van die 'tucht' (Biesterveld \& Kuyper 1905:9). Vir Wezel in 1568 staan die bedienaar van die Woord in diens van die drie merktekens van die ware kerk van artikel 29 van die NGB uit 1561 (NG Kerk-Uitgewers 1982:29): die Woordsuiwere bediening van Woord, sakrament en tug. Anders gestel, Wezel integreer die bediening van die Woord, sakramente en tug en maak daarvan 'n saamwerkende drieling.

Die sakramente is sigbare Woordverkondiging en daarom word dit gereserveer vir ' $n$ leeram $p^{7}$ of die bedienaar van die Woord. Anders as die Woord wat soms bloot 'n stigtelike woord of 'n proefpreek is, kan die sakramente egter nooit nie-amptelik bedien word nie. Die doop en die nagmaal kan nie voorlopig of nie-amptelik wees nie. Slegs die amptelike bediening daarvan kan sakramenteel of 'n teken en seël wees. Daarom moet die sakramente deur die amp van die bedienaar van die Woord in die kerklik-erkende erediens bedien word, al is dit ' $n$ buitediens en ' $n$ uitsondering. 'n Buitediens waaroor die ampte ook toesighou. ${ }^{8}$

\section{Waar word gedoop?}

Trimp wys daarop dat die doop voor en in die aanloop tot die Reformasie 'n saak tussen die priester wat die doop bedien en die ouers van die dopeling was. Die kern daarvan was die ingestorte genade van God in die dopeling. Die genade wat deur die bediening van die doop spontaan of ex opere operato sou werk en 'n private aangeleentheid is. Die plegtigheid het in 'n 'terzijde gelegennis' van die kerkgebou afgespeel. Die gereformeerdes het - tereg - egter verstaan dat die doop as ' $n$ sigbare of kerklik-gesanksioneerde verkondiging van die Woord, 'n geskenk van God aan die hele gemeente is en 7.Daar kan natuurlik meer as een leeramp in 'n kerk wees (Du Toit 1998:220). 8.Die Algemene Sinode van 1998 van die NGK bevestig dat proponente wat nie in die amp van die bedienaar van die Woord bevestig is nie, die Woord daarom nieamptelik bedien (NGK 1994:511). 
daarom in die erediens, net soos die verkondiging van die Woord, vanaf 'n sentrale punt bedien moet word. 'n Sentrale punt, omdat Woord en sakrament sentraal vir die kerk en die koninkryk is (NGK 1962:202) en die gemeente se antwoord saam daarop gerig moet wees. Deur die doop ontvang die gemeente die dopeling as ' $n$ nuwe lidmaat in sy geledere (dooplidmaat deur die verbonds- sowel as die volwasse doop) wat soos enige ander nuwe lidmaat in die gemeente of die magsgebied van God tuisgemaak word (Trimp 1983:163).

\section{By die Konvent van Wezel in 1568 is gevolglik besluit:}

De doop nu zal bediend worden met het gebruiklijke formulier, dat in de kerkelijke verordeningen voorgeschreven is. En dat wel nergens anders noch op enige andere wijze dan in de samenkomsten der kerk bij de prediking en de catechismus ... (Biesterveld \& Kuyper 1905:24).

Meer nog: die Woord wat die water by die doop verklaar, lê in sy kern op 'n belydenisvlak en daarom moet die doopsformulier ook so suiwer moontlik uit die kerk in breër verband kom. In die kerk is meer koppe - meestal - beter as een. Die gesamentlike verstaan van die doop in die kerkverband of van die gemeentes in die kerkverband, gee uitdrukking aan 'n kernwaarheid van die geloof, naamlik die genade van God wat lei tot kindskap by die gelowiges. Die formulier verwoord die belydeniseenheid van die kerk in hierdie saak (Trimp 1983:162). Deur hulle aanvaarding van die doopsformulier, opgestel deur die kerk in breër verband, skaar die liturg en die gemeente hulle deur die bediening daarvan by die heilige, algemene Christelike kerk. Boonop is op die gevaar van eensydighede gewys, dat individuele pogings van bedienaars tot ' $n$ krampagtige 'willekeur en dikwels ... verminking van ... formuliere' lei. De Klerk aanvaar dat 'n formulier die aard van 'n geloofsbelydenis en lering vertoon met heilswaarhede vir die gemeente. Volgens hom is instemming met doopwaarhede "n openbare belydenis van geloof' (De Klerk 1982:93; Trimp 1983:163).

\section{Doop in die erediens?}

Gereformeerdes glo dat die bediening van die doop in die erediens binne die raamwerk van Skrif en belydenis moet plaasvind. Dit is ' $n$ bediening waarvoor ' $n$ breër aanvaarde, voorgeskrewe formulier ' $n$ meer verantwoorde bydrae lewer. Die formuliere as die uitkoms van die geloofseenheid van die kerk in 'n breër verband, ontmoedig die verskraalde individualisme van die liturg en 'n gemeente-georiënteerde independentisme én verryk die bediening van die sakramente. ${ }^{9}$ Natuurlik kan bekendheid en 'n gebrek aan meer as een opsie tot die formele, uiterlike gebruik van die formuliere lei. Die formele karakter word egter ondervang met meer as een formulier en 'n deurleefde aanbieding van al

9.Die eerste Algemene Sinode van die Nederduitse Gereformeerde Kerk (1962) eerbiedig die ekumeniese karakter van liturgiese formuliere wat later, teen die einde van die 20ste eeu te midde van wisselformuliere en ' $n$ drastiese korting van
die lengte daarvan, deur hierdie instansie vermy word (NGK 1994:494, 511; die lengte daarvan, deur hierdie instansie vermy word (NGK 1994:494, 511;
2002:58, 538, 539; 2007:63). In kontras met van sy latere opvolgers besluit die $2002: 58,538,539 ; 2007: 63)$. In kontras met van sy latere opvolgers besluit die
Algemene Sinode van 1962 om saam met die Gereformeerde Kerk in Suid-Afrika Algemene Sinode van 1962 om saam met die Gereformeerde Kerk in Suid-Afrika
(GKSA) en die Nederduitsch Hervormde Kerk van Afrika (NHKA), die liturgiese (GKSA) en die Nederduitsch Hervormde Kerk van Afrika (NHKA), die liturgiese
formuliere te hersien (NGK 1962:127-128). In 2002 sê die Algemene Kommissie vir formuliere te hersien (NGK 1962:127-128). In 2002 sê die Algemene Kommissie vir
die Erediens boonop dat die formuliere nie 'altyd' by die bediening van die sakrament gelees hoef te word nie (NGK 2002:58). Die gevolg is ' $n$ groeiende, oewerlose slordigheid in die gereformeerde bediening (Strauss 2015:101). die punte van die formulier in 'n gekontroleerde - aan die hand van die formulier - parafrase. Soos by die herlees van bekende Skrifgedeeltes, moet die herlees van liturgiese formuliere deurgaans van die egtheid van die geloof van die liturg getuig. Waarhede oor die kern van die verhouding God-mens, kan nooit geyk raak nie. Die neiging in gemeentes én kerkverband om die formuliere tot 'n kort verwringde opsomming in te kort, voorspel 'n verskraalde geloofsinsig en -belewenis by die gemeente en die liturg en 'n devaluering van die sakrament. Daarom moet die geldige kerkorde hom hieroor uitlaat.

Smit en Van der Walt toon aan dat dit vanaf die Partikuliere (Provinsiale) Sinode van Dordrecht in 1574 in die NederlandsGereformeerde tradisie bepaal is dat 'die doop slegs in die erediens mag plaasvind' (Biesterveld \& Kuyper 1905:78-79). Die erediens is die samekoms van die verbondsgemeenskap of die gelowiges waar die bondelinge God amptelik of kerklikerkend ontmoet. Daarom hoort die doop as 'n goddellike en kerklike verseëling van die verbond in die erediens. Die sakramente as die sigbare bediening van die Woord, ons het daarop gewys, is 'onlosmaaklik' aan die bediening van die Woord gebonde. Die Woord wat die geloof verwek en die doop en die nagmaal wat die geloof versterk hoort saam (HK vr 65; NG Kerk-Uitgewers 1982:56). Smit en Van der Walt voltooi hulle betoog op hierdie punt juis met die stelling dat die doop as die beseëling van die verbond die 'inlywing' van die dopeling in die verbondsgemeenskap behels. Dit is dus 'van wesenlike belang' dat die doop in die erediens van die verbondsgemeenskap plaasvind (Smit \& Van der Walt 1989:65).

Die Nasionale Sinode van Dordrecht het wel in 1618-1619 bepaal dat 'groot nood' en buitengewone omstandighede mag lei tot 'n 'nooddoop' buite die normale erediens. Die oorsprong hiervan lê egter by die Rooms Katolieke Kerk wat die doop buite die erediens bedien om te verseker dat die dopeling ingestorte genade kry om as hy of sy sou sterwe, salig te wees. Dit gaan om die bygeloof dat die doop as 'n uiterlike seremonie - in die plek van Christus - salig maak en noodsaaklik is. Om aan die karakter van die doop getrou te bly, het Dordrecht in 1619 bepaal dat die nooddoop in 'n amptelike buitediens mag plaasvind (Biesterveld \& Kuyper 1905:16). Daarby het die Provinsiale Sinode van Delft, in die hitte van die stryd, in 1596 verklaar dat die saligheid nie van die doop afhanklik is nie (Smit \& Van der Walt 1989:63).

\section{Wie word gedoop?}

Vir gereformeerdes is die doop 'n verseëling van die genadeverbond van die Here aan die kinders van die gelowiges met die gemeentelede in die erediens as die deelnemende getuies (De Klerk 1982:92). Daarom bepaal die Nasionale Sinode van Dordrecht in 1619 in sy Kerkorde artikel 56 dat die verbond aan die kinders van die Christene 'verzegeld worden, en dat in de openbare verzameling, wanneer Gods Woord gepredikt wordt' (Biesterveld \& Kuyper 1905:241). 
In die $\mathrm{Ou}$ Testament is die seuntjies van gelowiges op 8 dae besny as 'n verseëling van die verbond van genade. Gereformeerdes glo dat die doop in die Nuwe Testament seremonieel verdiepend in die plek van die besnydenis gekom het. Trimp (1985:60-61) oordeel dat die doop as die besnydenis van Christus of die 'Christelijke besnijdenis' laasgenoemde impliseer.

In Kolossense 2:11 en 12 word die geestelike of innerlike doop van mense deur God in verband gebring met sy geestelike besnydenis wat 'bestaan in die wegneem van die sondige natuur van die mens', 'n nuwe geestelike geboorte én die geloof (Strydom 2014:40). Die wegneem van die sondige natuur deur die geestelike doop (1 Kor 12:13 gebruik die uitdrukking om 'met die een Gees' tot een liggaam gedoop te wees om te toon dat die Heilige Gees die belyers van Jesus as die Here - vers 3 - of liggaam van Christus geestelik doop) van die Heilige Gees as die besnydenis van Chistus, word verbind aan die begrafnis van Christus - die mens sterf sy sondige natuur af - én sy opstanding waardeur die gelowiges 'saam met Hom (sterwe en) opgewek' is. Trimp (1985:61) verstaan dit so dat Kolossense 2 oor die geestelike rykdom van die doop praat, die sin van die besnydenis in die doop opneem en die besnydenis as ' $n$ 'aparte ceremonie overbodig maakt'.

Die Here sluit ' $n$ verbond met die gelowiges en hulle kinders. 'n Genadeverbond wat as 'n ooreenkoms twee kante het: dié van beloftes en eise. Hy belowe dat hy vir hulle 'n God sal wees, maar eis dat hulle sy gelowige, gehoorsame kinders moet wees. 'n Verbond wat Hy eensydig of monopleuries instel en wat sonder enige inset van hulle kant die weg van hulle ewige verlossing aandui. ' $n$ Verbond waarbinne hulle hier en hierna lewe en sal lewe. 'n Verbond wat die genade en nuwe lewe in God aan mense wat in sonde ontvang en gebore en van nature doodgebore is vir sy beloftes en eise, oordra (Kock sa:8-9; Ef 2:1 e.v.).

Romeine 11:33-36, 'n loflied op God se verkiesing om te begenadig, of op sy genadige verordinering, sing dit uit:

O diepte van die rykdom en wysheid en kennis van God! Hoe ondeurgrondelik is sy oordele, hoe onnaspeurlik sy weë! Wie ken die bedoeling van die Here? Wie gee Hom raad? Wie bewys Hom 'n guns, sodat Hy verplig is om iets terug te doen? Uit Hom en deur Hom en tot Hom is alle dinge. Aan Hom behoort die heerlikheid tot in ewigheid! Amen.

Die Here sluit sy genadeverbond met die gelowiges en hulle kinders. Daarom word nie-gedoopte, meer volwasse kinders of volwassenes wat tot geloof en bekering kom, deur die doop uiterlik verbind aan 'n nuwe verbondslyn: hulle en hulle kinders ten opsigte van wie hulle belowe om hulle op te voed om positief op die eise van die verbond te antwoord soos dit deur Woord en belydenis oorgedra word. 'n Verbondslyn wat met die ingryp van die Here in hulle lewens 'n werklikheid geword het (De Klerk 1982:94).

Wanneer moet gebore verbondskinders ten doop gebring word? Die uitgangspunt is natuurlik dat die doop self nie salig maak nie, maar 'n teken en seël van God se genade is. 'n Teken en seël wat die tyd van doop moet bepaal en nie familietradisies, wanneer sekere 'sleutelfigure' teenwoordig kan wees of wanneer dit met 'n nie-kerklike eet en drink gepaard kan gaan nie.

Die slotsom van gereformeerde kerkordes in die Nederlandse lyn hieroor is: '. . zo spoedig mogelijk' (Nauta 1971:255; Smit \& Van der Walt 1989:61). Die doop verseël die feit dat 'n verbondskind as kind van verbondsouers binne die genadeverbond gebore is. Die verseëling van 'n belofte wat nie menslik onverskillig deur nie-kerklike faktore bepaal of uitgestel moet word nie, maar so gou moontlik in die lewe van 'n verbondskind moet plaasvind (Kruger et al. 1966:340). Die Algemene Sinode van 2002 van die NGK neem 'n besluit (NGKO 2002 artikel 49.1) waarin aanbeveel word dat die doop 'so gou as moontlik' aangevra en bedien word (NGKO 2002:20).

Aan die ander kant kan gevra word: Tot op watter ouderdom kan kinders van verbondsouers wat ook Christelik opgevoed word, gedoop word? Kerkregtelikes meen dat die kinders nog op so 'n stadium van hulle ontwikkeling moet wees dat hulle in die Christelike godsdiens opgevoed moet word. As hulle so ver ontwikkel het dat hulle self verantwoordelikheid vir hulle geloofslewe kan aanvaar, moet hulle gereedgemaak word vir die volwasse doop (Smit \& Van der Walt 1989:64). In die NGK het die gebruik ontwikkel om verbondskinders, na 'n gesprek met die ouers oor hulle versuim, tot op 7 jaar te doop en daarna, voor die aflegging van belydenis, na 'n eenvoudige belydenis van geloof te doop (Kleynhans 1988:56-62).

\section{Wie laat doop?}

Die verbondsdoop van die kinders van gelowige ouers plaas die vraag op die konsistorietafel: Wie mag laat doop? Wie mag as die wettige, bekwame ouers of voogde van die betrokke kinders hulle laat doop en wie kan onderneem om hulle gehoorsaam aan God groot te maak? Wie mag hulle kinders laat doop en met reg daarop aanspraak maak dat hulle hierdie kinders Christelik sal opvoed en laat opvoed?

Die opgesomde antwoord op hierdie vraag is dat een of albei lede van 'n egpaar, ouers of voogde wat die beloftes van die verbondsouers geloofwaardig én as wettige ouers of voogde kan aflê, kinders kan laat doop. Om aan die doopbeloftes uitvoering te gee, moet die aanneming, pleegsorg of voogdyskap wetlik en van 'n permanente aard wees (NGK 1986:343, 566, 671; 1990:350; 1994:587). Al is net een van die ouers 'n lidmaat van die gereformeerde gemeente of 'n erkende gereformeerde kerk, kan dié persoon die beloftes aflê. Slegs kerklik-geloofwaardige ouers of voogde kan toegelaat word om die beloftes wat 'n gesonde band met die Here by die wat laat doop impliseer, af en lê. Ander ouers of voogde as hierdie sou as 'n lid van 'n ouerpaar kon bystaan sonder om die vrae te beantwoord. 'n Gelowige wat met' $n$ ongelowige getroud is, kan die beloftes alleen aflê. 'n Kindjie wat voorhuweliks gebore is, kan 
gedoop word as een of albei ouers die buitehuwelikse geboorte met die Here én die kerk as toesighouer, uitklaar en die beloftes in nuwe omstandighede geloofwaardig kan aflê. Ouers of voogde wat weens onbekeerde ergerlike gedrag onder tug is, bring die geloofwaardigheid van die beloftes vanweë hulle onbuigsaamheid in die gedrang. Wetlike ouers wat deur wetlik-erkende geboorte, aanneming, pleegsorg en voogdyskap in staat is om daaraan uitvoering te gee, kan, indien kerklik-geloofwaardig, die beloftes aflê (Smit \& Van der Walt 1989:62-64).

\section{Hoe word gedoop?}

De Klerk wys daarop dat daar hoofsaaklik drie maniere van doop by die Christelike kerke voorkom: onderdompeling, begieting en besprenkeling. Vir al drie bestaan daar bybelse gronde. Behalwe om aan te toon wat die water simboliseer, laat ons die saak vir die doeleindes van hierdie artikel daar. Smit en Van der Walt oordeel dat die wyse waarop die water by die doop gebruik word, 'n middelmatige saak is waarvoor daar nie apostoliese voorskrifte is nie. Die water dui in elk geval op reiniging deur die bloed van Christus (De Klerk 1982:91; Smit \& Van der Walt 1989:66-67).

Daar is reeds daarop gewys dat die doop te make het met die genadeverbond van die Here waarby die dopeling ingelyf word. 'n Genadeverbond waarin die Here Hom as hulle God aan die bondelinge verbind; ' $n$ verbond wat Hy deur die doop aan hulle verseël; 'n verbond met 'n beloftekant en 'n eisekant - eise wat die antwoord van die bondelinge bepaal.

Verder is daarop gewys dat die reformatore teen die weder- of herdoop gekant was. Reeds in die Reformasie met sy skerp kritiek op die Roomse Kerk, is gevra watter doop deur gereformeerdes erken word? Watter doop van ander kerke en groepe kan beskou word as geldig? Daarby, wat impliseer die herdoop indien iemand weer gedoop word? Die afspraak sedertdien is: ' $n$ erkende doop moet in die Naam van GodDrieënig, Vader, Seun en Heilige Gees wees, met water gedoen en deur 'n voorganger van die betrokke kerk of geloofsgemeenskap bedien word (Strydom 2014:41). Teenoor die Donatiste en die Wederdopers het Calvyn geglo dat die krag of effek van die doop nie afhang van die Christelike waardigheid van die een wat dit bedien nie, maar van GodDrieënig wat dit gee. Daarby bevraagteken herdoop God se beloftes en dus sy geloofwaardigheid. 'n Verskynsel wat sy Woord ook in die gedrang bring (Sizoo sa:360-361; Smit \& Van der Walt 1989:62). Die Algemene Sinode van 2002 van die NGK oordeel dat 'omtrent alle kerke in die wêreld', selfs hulle wat die verbonds- of kinderdoop afkeur, die herdoop verwerp. Volgens hierdie Sinode is dit 'n dwaling wat 'hoegenaamd nie in die kerk geduld mag word nie' (NGK 1994:594).

In 2007 keur die Algemene Sinode van die NGK 'n viering of herdenking van die doop in die lewe van lidmate goed. 'n Viering wat nie die indruk van 'n herdoop moet skep nie (NGK 2002:621). Na 'n koerslose rondtrappery aanvaar die Algemene Sinode van 2011 die Handboek vir die erediens wat impliseer dat die viering van die nagmaal as die teken en seël van inblywing in die verbond volg op die doop as die teken en seël van inlywing in die verbond (NGK 2011:93). Dat die doop - tereg - as 'n sakrament van God tydens die nagmaal as 'n sakrament van God gevier word. 'n Sakrament wat in betekenis ver bo enige mense-seremonie uitstaan.

Dit bring ons by die gevallestudies van die prosedure by die verbondsdoop deur twee gereformeerde kerkordes: die GKSA-KO en NGKO. Studies en 'n evaluering wat die betoog tot dusver as agtergrond gebruik en gevolgtrekkings opbouend bedoel. Wat ons tot dusver as uitgangspunte of hoofoogmerke vir die prosedure by die bediening van die doop blootgelê het, is die volgende.

Die doop verseël as 'n godgegewe genademiddel die inlywing in die genadeverbond van God. Dit gaan om God-Drieënig wat inisiërend ten opsigte van ons heil en verlossing handel en die mens wat positief daarop moet antwoord. Die doop is sigbare, amptelike Woordverkondiging en daarom deel van die taak van die bedienaar van die Woord in die gemeente as 'n betrokke verbondsgemeenskap. Die doop vind in 'n kerklik-erkende erediens plaas. Woordverkondiging in die diens mik op die sentraliteit van God-Drieënig in hierdie proses van genade: die Vader deur sy genadige bestemming en beskikking, Christus deur sy sterwe en opstanding as Middelaar en Verlosser, en die Heilige Gees as die Brugbouer met die Woord van God tussen God en mens. As 'n sigbare teken gaan die doop om gewone skoon water, verbind aan die doopformulier as ' $n$ produk van ' $n$ belydenisaard uit, ten minste, die eie kerkverband. 'n Formulier wat, soos die Heilswoorde van God, geglo moet word om die water in die konteks te plaas van geestelike reiniging en vryspraak deur God en die inlywing van die dopeling in die verbond van die Here. 'n Formulier of bewoording wat van die teken (water), die betekende saak (reiniging van sonde) maak. 'n Betekende saak wat deur die Heilige Gees aan die hart van die gelowige verseël word. Natuurlik kan 'n kerkorde nie bepalings neerlê vir die Heilige Gees nie en nie die mens se gelowige aanvaarding van die betekende saak 'beveilig' nie. Die Heilige Gees alleen waarborg die verseëling van die sakrament. As 'n kerkorde egter die prosedure vir 'n Woordsuiwere bediening van die doop neerlê, beantwoord hy aan sy Geesgedrewe oogmerk en laat hy ruimte vir die verseëling van die boodskap van die sakrament. Om onsekerheid hieroor by gemeentes te vermy, kan die kerkorde bepaal dat die verseëling van God se verbond van genade so gou moontlik moet plaasvind. In sommige gereformeerde kerke is hierdie 'so gou (spoedig) moontlik' 'n diepgesetelde kerklike tradisie (Nauta 1971:255; Pont 1981:183; Visser 1999:222).

\section{Die doop in die GKSA-KO}

Die GKSA-KO, artikel 56 tot 60, gee 'n aantal kernbepalings vir die doop (CJBF 2015:30-31). Hierteenoor trek NGKO sy bepalings vir die doop in een artikel saam, NGKO artikel 49.1 (NGKO 2017:14). Hierdie verskynsel hang saam met die feit dat die GKSA-KO die DKO ten opsigte van die aantal artikels 
en die inhoud van genommerde artikels meer letterlik navolg as die NGKO. Die DKO gee ook in artikels 56 tot 60 bepalings vir die doop (Pont 1981:183).

Die GKSA-KO val weg met die 'so spoedig moontlik-tradisie'.

Artikel 56 bepaal dat die verbond van God 'so spoedig moontlik' aan die kinders van Christene - GKSA-KO gebruik dieselfde woord as DKO artikel 56 - in die 'erediens' met die doop verseël word. Dit is 'n sakrament wat bedien word met die vasgestelde formulier. Die aanduiding van ' $n$ of een vasgestelde formulier weerspieël die heersende houding van die GKSA op sinodale terrein oor wisselformuliere. GKSA$\mathrm{KO}$ artikel 50 steek ook dadelik na die kern deur, deur die stelling dat die 'verbond van God' aan genoemde kinders 'beseël' word. 'n Woordgebruik - 'verbond van God' - wat teruggryp op DKO 1619 en 'n deftige ou-Afrikaanse 'beseël' wat die Nederlandse 'verzegeld worden' moet vertaal. GKSAKO omskryf die doop soos dit in hierdie artikel verduidelik word: 'n verseëling van die genadeverbond van God.

GKSA-KO artikel 57 gee aan die bedienaars (GKSA-KO volhard met hierdie Dordtse benaming vir die amp) opdrag dat hulle sal toesien dat die vader, moeder of voogde 'die doop vir hulle kinders ... aanbied'. Die opdrag van 'so spoedig moontlik' word dus vir geestelike kontrole aan die bedienaars toegewys. Dit is 'n opdrag wat net sowel op die agenda van die betrokke ouderling kon beland het. Artikel 58 reël dat die bedienaar by die doop van 'klein kinders sowel as van volwasse persone' die formuliere gebruik wat daarvoor vasgestel is. Die GKSA se gehegtheid aan die betrokke formulier as 'n dokument met 'n sterk kerklike status, blyk ook hieruit. GKSA-KO artikel 59 bepaal dat volwassenes deur die doop as lidmate van die kerk 'ingelyf ${ }^{\prime 10}$ word - dit volg waarskynlik op die belydenis van geloof - en is daarom verplig om die nagmaal te gebruik soos wat hulle by die doop belowe. GKSA-KO artikel 60 reël die onderhoud van doopregisters.

In sy geheel kan die GKSA-KO oor sy bepalings ten opsigte van die bediening van die doop deurgaan as Dordts én eietyds. Hierdie oriëntering blyk nie net uit sy 'so spoedig moontlik' nie, maar ook uit doop in die erediens deur ' $n$ bedienaar van die Woord, doop met die sinodaal-aanvaarde formulier en die siening van die doop as 'n 'beseëling' van die dogmaties-leerstelligomskrewe verbond van God. In afsonderlike sinodale besluite gee die GKSA detail oor wie die doop mag bedien, wie gedoop mag word, die onnodige vertraging van die doop en eenvormigheid in die dooppraktyk (CJBF 2015:30). 'n Saak uit die gestelde konstituerende elemente van die doop wat nie eksplisiet deur GKSA-KO artikel 56 tot 60 genoem word nie, maar deur sy woordgebruik en die verwysing na die formuliere tog aan die bod kom, is die beklemtoning van die doop as die inlywing in sy genadeverbond deur God-Drieënig. Die inlywing in die verbond, liggaam of kerk waarin elke Persoon van God-Drieënig sy rol speel.

10.Ons eie aanvaarding van die term 'inlywing' in die verbond-en verbondsgemeenskap kry hiermee erkenning.
Die nuwe doop- en nagmaalsformuliere van die Algemene Sinode van 2018 van die GKSA benadruk die verlossingswerk van, letterlik, God-Drieënig in nie-geykte kerktaal. Nuwe kerktaal met nuwe begrippe wat dui op voortgaande reformasie vanuit 'n soliede verbondsbeskouing. Die nuwe formulier vir die doop van 'kinders' bestaan uit drie hoofdele: die HK se sonde, verlossing en dankbaarheid. Volgens hierdie formulier geskied die doop in die Naam van die Vader, die Seun en die Heilige Gees. Aan elkeen van God-Drieënig word 'n rol in die verseëling van God se genadeverbond toegedig. Die Vader verseël sy genadeverbond, die Seun verseël die afwassing van die sonde deur sy bloed met die oog op inlywing in die liggaam van Christus en die Heilige Gees verseël dat $\mathrm{Hy}$ in ons wil woon en ons as lidmate van Christus wil heilig. Die HK se belydenis van die sakramente as tekens en seëls van die 'belofte van die evangelie', spreek deurgaans in hierdie formulier mee.

Daarmee het GKSA-KO 'klare wyn' geskink ten opsigte van sy prosedure vir die bediening van die doop in die gemeentes of kerke van die GKSA. Enersyds werk GKSA-KO met 'n dogmaties-verantwoorde, konstante doopbeskouing uit die Nederlands-Gereformeerde tradisie van die sestiende en sewentiende eeu en andersyds taalkundig en begripsmatig hervormend in die een-en-twintigste eeu.

\section{Die doop in die NGKO}

In teenstelling met die eerste NGKO artikel 49.1 in 1962 (NGKO 1962:10), is NGKO 2017 artikel 49.1 (NGKO 2017:14) wat meer uitgebreid en beter ingestel op die gestelde voorwaardes vir die kerkordelike prosedure by die bediening van die doop is.

In 1962 bepaal artikel 49.1 kortweg dat die doop deur bedienaars van die Woord in die erediens bedien word, 'behalwe by hoë uitsondering'. Hierdie artikel gee dus uitvoering aan net twee gestelde voorwaardes vir die bediening van die doop: dit geskied deur 'n (erkende) bedienaar van die Woord en in 'n (amptelike) erediens. In 2017 bepaal artikel 49.1 bykomstig dat die bedienaar van die Woord water en 'n goedgekeurde liturgiese formulier gebruik en dit in die 'amptelike openbare samekoms van die gemeente'. Die goedgekeurde formulier bevat dus die element van die Woord as betekenend vir die betekende saak én die erediens word omskryf as 'n amptelike samekoms van die gemeente as verbondsgemeenskap met oop deure of 'n openbare karakter.

Teen 2017 staan die NGK op wisselformuliere met respek vir die goedkeuring daarvan in kerkverband (deur die Algemene Sinode) en die bediening van die doop as amptelike, sigbare Woordbediening. Soos by die GKSA wil dit voorkom asof die nadruk op die Naam van God-Drieënig as die inisieerder en gewer van die sakrament as die sentrale figuur in die seremonie, en die betekenis van die water gekoppel aan die betekende saak in die formulier, indien dit aan die bod kom, aandag kry. Dat die doop die genadeverbond van God aan 
die mens verseël en dat dit hier gaan om inlywing in die verbond wat 'so gou as moontlik' moet geskied, ontbreek egter. Die Algemene Sinode van 2002 besluit egter om NGKO artikel 49.1 met sinodebesluite te versterk. Dit is besluite wat onder artikel 49.1 in NGKO gedruk word en vir iemand wat NGKO raadpleeg verduidelikend en byderhand is. Hierdie besluite toon watter lidmate kinders of 'verbondskinders' ten doop kan bring; dit bepaal dat die doop van verbondskinders 'so gou as moontlik' moet plaasvind; reël hoe kinders ouer as 7 jaar, maar voor belydenisaflegging op 16 jaar, gedoop word én gee prosedure vir die doop van persone ouer as 16 jaar na 'n openbare belydenis van geloof. Die besluite eindig met die erkenning van die doop van iemand uit ' $n$ ander kerk, mits dit aan die gestelde drie vereistes voldoen (NGKO 2002:20).

Hierdie aanvullende besluite wat uit 'n praktiese oogpunt die gestelde prosedure rondom die doop in een dokument saamtrek, word in 2011 egter weer uit NGKO verwyder. Daarmee verdwyn die 'so gou as moontlik'-tradisie ook uit die NGKO.

Dit wil uit hierdie betoog dus voorkom asof die NGKO artikel 49.1 om nuwe aandag vra.

\section{Slot}

Tipies van 'n kerkorde en die kerkreg, is die vraag na 'n kerkorde en die doop 'n vraag met meer as een veronderstelling.

Kerkorde en doop fokus op die prosedure van hierdie orde vir die bediening van die doop. Dit handel oor ' $n$ orde wat die Skrifgetroue, dogmaties-vasgestelde doop wil bedien met ' $n$ prosedure wat die aard daarvan by die bediening daarvan beveilig en beskerm. Dit is 'n prosedure wat die sakrament dien of help om sy boodskap sakramenteel tuis te bring en wat die sakramentele karakter van die sakrament probeer - soos die kerk as 'n geloofsinstelling werk sy kerkorde ten diepste met oortuiging - beveilig. By die doop onder gereformeerdes bestaan hierdie beveiliging uit 'n ordelike raamwerk vir die moontlikheid dat die doop inlywing van die dopeling in die verbond van God bevestig en verseël. Die kerkordelike prosedure wil die Skrifmatige bediening van die doop as 'n aksie van God-Drieënig benadruk en beskerm. Hiervoor leen die kerkorde by die Skrif en die dogmatiek, hoewel dit self op die kerklike prosedure en kerkreg as 'n dienende reg ingestel bly.

\section{Erkenning \\ Mededingende belange}

Die outeur verklaar dat hy geen finansiële of persoonlike verbintenis het met enige party wat hom nadelig kon beïnvloed in die skryf van hierdie artikel nie.

\section{Outeursbydrae}

P.J.S. was die enigeste outeur betrokke by die skryf van die artikel.

\section{Etiese oorwegings}

Hierdie artikel volg alle etiese standaarde vir navorsing sonder direkte kontak met mens of dier.

\section{Befondsing}

Hierdie navorsing het geen spesifieke toekenning ontvang van enige befondsingsagentskap in die openbare, kommersiële of nie-winsgewende sektore.

\section{Data beskikbaarheidsverklaring}

Data-deling is nie van toepassing op hierdie artikel nie, aangesien geen nuwe data in hierdie studie geskep of ontleed is nie.

\section{Vrywaring}

Die sienings en menings wat in hierdie artikel uitgedruk word, is dié van die outeur (s) en weerspieël nie noodwendig die amptelike beleid of posisie van enige geaffilieerde agentskap van die outeurs nie.

\section{Literatuurverwysings}

Bavinck, H., 1967, Gereformeerde Dogmatiek, 4, Kok, Kampen.

Biesterveld, P. \& Kuyper, H.H., 1905, Kerkelijk handboekje, Bos, Kampen.

Bouwman, H., 1985, Gereformeerd Kerkrecht, 2, De Groot Goudriaan, Kampen.

Calvyn Jubileum Boekeffonds, 2015, Kerkordeboekie van die Gereformeerde Kerke in Suid-Afrika, CJBF en AdminstratieweBuro, Potchefstroom.

CJBF, kyk Calvyn Jubileum Boekefonds

Coertzen, P., 1991, Gepas en ordelik, RGN-Uitgewery, Pretoria.

De Jong, O., 1987, Geschiedenis der kerk, Callenbach, Nijkerk.

De Klerk, J.J., 1982, Liturgiese grondlyne, NG Kerk-Uitgewers, Kaapstad.

Dingemans, G.D.H., 1987, Een hu om in te wonen, Boekencentrum, Den Haag.

Du Toit, A.B., 1998, Ondersoek na 'n Nuwe Testamentiese basis vir die heraanpassing van die bedieningstruktuur in die Nederduitse Gereformeerde Kerk, Nederduitse Gereformeerde Kerk, Handelinge van die Algemene Sinode, s.n., s.I.

Heick, O.W., 1965, A history of Christian thought, Fortress, Philadelphia, PA.

Heyns, J.A., 1973, Die brug tussen God en mens, NG Kerk-Uitgewers, Kaapstad.

Jonker, H., sa, Liturgische oriëntatie, 2e dr., Zomer \& Keunings, Wageningen.

Jonker, W.D., 1965, Om die regering van Christus in sy kerk, Unisa, Pretoria.

Kleynhans, E.P.J., 1984, Gereformeerde Kerkreg, dl 2, NG Kerkboekhandel, Pretoria.

Kleynhans, E.P.J., 1988, Gereformeerde Kerkreg, dl. 4, NG Kerkboekhandel, Pretoria.

Kock, P. de B., sa, Riglijies vir belydeniskatkisante, Sentrale Pers, Bloemfontein.

Kock, P. de B., 1975, Christelike wysbegeerte - inleiding, Sacum, Bloemfontein.

Kruger, L.S., Du Plessis, H.L.M., Spoelstra, B. \& Spoelstra, T.T., 1966, Handleiding by die kerkorde, Pro Rege, Potchefstroom.

Nauta, D., 1971, Verklaring van de kerkorde van de Gereformeerde Kerken in Nederland, Kok, Kampen.

Nederduitse Gereformeerde Kerk, 1962, Handelinge van die Algemene Sinode, sn, sl.

Nederduitse Gereformeerde Kerk, 1966, Handelinge van die Algemene Sinode, s.n., s.l.

Nederduitse Gereformeerde Kerk, 1974, Handelinge van die Algemene Sinode, s.n., s.l.

Nederduitse Gereformeerde Kerk, 1986, Handelinge van die Algemene Sinode, s.n., s.l.

Nederduitse Gereformeerde Kerk, 1990, Handelinge van die Algemene Sinode, s.n., s.l.

Nederduitse Gereformeerde Kerk, 1994, Handelinge van die Algemene Sinode, s.n., s.l.

Nederduitse Gereformeerde Kerk, 1998, Handelinge van die Algemene Sinode, s.n., s.l.

Nederduitse Gereformeerde Kerk, 2002, Handelinge van die Algemene Sinode, s.n., s.l. 
Nederduitse Gereformeerde Kerk, 2004, Handelinge van die Algemene Sinode, s.n., s.l.

Nederduitse Gereformeerde Kerk, 2007, Handelinge van die Algemene Sinode, s.n., s.l.

Nederduitse Gereformeerde Kerk, 2011, Handelinge van die Algemene Sinode, s.n., s.l.

Nederduitse Gereformeerde Kerk, Kerkorde, 1962, Kerkorde van die Nederduitse Gereformeerde Kerk, NG Kerk-Uitgewers, Kaapstad.

Nederduitse Gereformeerde Kerk, Kerkorde, 1964, Kerkorde van die Nederduitse Gereformeerde Kerk, NG Kerk-Uitgewers, Kaapstad.

Nederduitse Gereformeerde Kerk, Kerkorde, 2002, Kerkorde van die Nederduitse Gereformeerde Kerk, Lux Verbi.BM, Wellington.

Nederduitse Gereformeerde Kerk, Kerkorde, 2017, Kerkorde van die Nederduitse Gereformeerde Kerk, Die Kerkorde, s.n., s.I.

NG Kerk-Uitgewers, 1982, Ons glo ..., NG Kerk-Uitgewers, Kaapstad.

NGK, kyk Nederduitse Gereformeerde Kerk

NGKO, kyk Nederduitse Gereformeerde Kerk Kerkorde
Plomp, J., 1992, 'Kerk en recht', in W. van 't Spijker \& L.C. van Drimmelen, Inleiding tot de studie van het kerkrecht, bl. 32-42, Kok, Kampen.

Pont, A.D., 1981, Die historiese agtergronde van ons kerklike reg, 1, HAUM, Pretoria.

Sizoo, A., s.a., Johannes Calvijn Institutie IV, Meinema, Delft.

Smit, C.J. \& Van der Walt, J.J., 1989, Die doop in die Gereformeerde Kerkorde, In die Skriflig 23(2), 59-73.

Strauss, P.J., s.a., Die Gees werk soos Hy wil ..., VCHO, Bloemfontein.

Strauss, P.J., 2010, Kerk en orde vandag, SunMedia, Bloemfontein.

Strauss, P.J., 2015, Gereformeerdes onder die Suiderkruis 1652-2011, SunMedia, Bloemfontein

Strydom, M., 2014, 'n Narratiewe benadering tot die interpretasie van die doop en belydenisaflegging, MDiv-skripsie, UP, Pretoria.

Trimp, C., 1983, De gemeente en haar liturgie, Van den Berg, Kampen.

Trimp, C., 1985, Woord, water en wyn, Kok, Kampen.

Van der Linde, G.P.L., 1983, Die Kerkorde, Van Wyk, Pretoria.

Visser, J., 1999, Die Kerkorde in praktyk, EFJS, Orkney. 